\title{
Farmer experience with tree fodder
}

\author{
J.F.L. CHARLTON ${ }^{1}$, G.B. DOUGLAS ${ }^{2}$, B.J. WILLS ${ }^{3}$ and J.E. PREBBLE ${ }^{4}$ \\ ${ }^{1}$ Greenfields Communications, 17 Cremorne Avenue, Palmerston North \\ ${ }^{2}$ AgResearch, Grasslands Research Centre, Private Bag 11008, Palmerston \\ North \\ ${ }^{3}$ AgResearch, PO Box 228, Alexandra, Otago \\ ${ }^{4}$ Farmer, Mt Blue, Palmerston, RD3, Dunback, Otago \\ dericpat@ihug.co.nz
}

\begin{abstract}
Use of trees for drought feed on New Zealand farms has been practised sporadically for many years, after farmers found that tree prunings were useful as supplementary feed during summer droughts. The Ministry of Agriculture \& Forestry (MAF) Sustainable Farming Fund recently funded a farmer-led team to develop the concept of tree fodder use on livestock farms in the southern North Island. Livestock farmers in Hawke's Bay, Rangitikei and Wairarapa who are already using tree fodder were interviewed to generate practical guidelines from their experience. Additional experience from Otago has been included here.

Farmers obtain tree fodder by pruning and pollarding soil conservation trees, and by coppicing or grazing livestock on fodder blocks, or by taking advantage of natural leaf fall from poplar trees. The most common practice was pruning willows and poplars originally planted for soil conservation, during summer using a chainsaw. Most farmers found tree fodder feeding a valuable practice and well worthwhile. Over a three-tofour week period, two farmers reported taking 1.5-2 hours per day to feed 1,000 sheep, or cutting five or six trees per day to feed approximately 1,000 ewes.
\end{abstract}

Keywords: tree fodder; poplars; willows; coppicing; pruning.

\section{Introduction}

Using trees as fodder for livestock is as old as The Bible (Genesis Chapter 31) and for many years some New Zealand farmers have resorted to cutting trees, especially poplars and willows planted mainly for soil conservation purposes, especially in the dry East Coast regions (P Manson, J. Pottinger, pers. comm.; Treeby 1978; Poole 1983; Wilkinson 1999).

In many countries, tree fodder is fed to farm animals as common practice, because their summers are always too harsh for pasture to grow (Everist 1958; San Miguel \& Gonzalez 1985; Schwartz et al. 1988; Nautiyal 1991). Australian farmers have survived through droughts that persist for several years by feeding surviving stock on drought-tolerant trees (F.C. Crofts, pers. comm.), and tree fodder has been investigated in several other drought-prone countries. 
Over the past three years, the Ministry of Agriculture \& Forestry (MAF) Sustainable Farming Fund (SFF) has funded a project to promote tree fodder use by livestock farmers. In addition to promoting results from research trials with poplar and willow foliage fed to sheep at Massey University's Riverside Farm (funded by AGMARDT, Greater Wellington Regional Council and Massey University), the SFF Tree Fodder group is studying fodder block establishment and management at Riverside Farm in Wairarapa and Hawke's Bay, determining tree fodder value, and holding on-farm demonstrations in Hawke's Bay, Rangitikei and Wairarapa.

One of the group's first activities was to identify livestock farmers in Hawke's Bay, Rangitikei and Wairarapa, who were already using tree fodder to some extent, so that their valuable experiences could form the main basis of guidelines for farmers. This paper reports on findings from these interviews and incorporates farmer experience from Otago, another region that has made some effort to document and develop the tree fodder concept.

\section{Using trees as fodder}

Farmers usually harvest trees for supplementary fodder by pruning and pollarding the poplars and willows they planted for erosion control, or by coppicing or grazing livestock on fodder blocks, and some also take advantage of natural leaf fall from poplar trees and leave animals in paddocks for this purpose.

\section{Pruning and pollarding soil conservation trees}

Soil conservation willows and poplars are commonly pruned during summer. These trees are extensively planted for soil conservation in hill country where soils are prone to gully or slip erosion, arising mostly from surplus soil water (van Kraayenoord \& Hathaway 1986). Regional councils distribute thousands of poplar and willow poles annually for on-farm planting. Willows tend to be favoured for wetter sites and where the prevailing wind speed is relatively high.

These trees are grown vegetatively from either stakes or wands, which are stems cut at 1.0-1.2 m lengths, or as poles (2.0-3.0 metres long). These units vary in diameter, the longer usually being thicker. In the southern North Island, regional councils supply the following poplar and willow poles and wands every year (P. Cameron, N. Faulknor, K.Rooke, pers. comm.):

- Horizons Regional Council - grow 5,000 poles and 10,000 willow wands (similar numbers supplied through private nurseries) annually.

- Hawke's Bay Regional Council - 20,000 $\times 2.5 \mathrm{~m}$ and $3.0 \mathrm{~m}$ poles, the main categories supplied for soil conservation on farms.

- Greater Wellington Regional Council - 26,000 poles on average per year, supplied from the Akura Conservation Centre, Masterton. 
As a result, hill country pastures in these regions are well covered by widely spaced (usually 20-50 trees/ha) poplars and willows, especially in erosion-prone gullies. In Hawke's Bay and Wairarapa, annual rainfall is at least 1,000 mm, but the pasture feed supply declines in most summers and in drought years is in short supply until late winter (Hyslop 1999). However, these regions can suffer serious flooding and subsequent erosion events during winter storms, as some widespread soil types are very prone to movement.

In Otago, the regional council operates a commercial operation, with IHC, the New Zealand Society for the Intellectually Handicapped, running the Barnego Nursery. The Otago Regional Council has little or no involvement in tree sales, but undertakes the resource management and marketing through its normal regulatory operation. A similar procedure applies in Canterbury.

Planted poles must be protected from farm livestock for up to three years using fencing or plastic sleeves. Thereafter they provide valuable fodder for many years and also supply shade, shelter and encourage bird life. One farmer (Olsen, Rissington) has 30-year-old trees grown from poles that have been used for fodder many times, and remain as productive as ever. Poles grow rapidly after planting and trees can become a serious hazard to farmers and livestock if not regularly trimmed, as their long branches break readily during storms (McGregor, Waipawa). Once established, a farmer should pollard these trees at a level high enough to prevent cattle browsing. Regrowth will form a bushy tree that offers shelter and shade, yet can be more easily pruned at regular intervals.

A chainsaw is useful when operating from ground level, and a special-purpose pruning chainsaw or hand-pruning saw should be used when pruning higher up a tree, using an approved forestry pruning ladder. To feed stock, the farmers interviewed start by felling trees to reduce planting densities, and consider this easiest and quickest for feeding. Pruning trees from the ground or a ladder is slower than harvesting excess trees, and takes more time to generate feed in quantity. All pruning is along forest silviculture lines in that the farmer prunes to shape a tree by pollarding it, or thins a stand by cutting trees at ground level (A Olsen, pers. comm.). Trees are much easier to handle when they are young and small, so using them for fodder keeps them trimmed to convenient shape and size (Gawith, Longbush).

Pollarding a 5-10-year-old tree at $2.0-2.5 \mathrm{~m}$ high, so that its regrowth ultimately forms a "pruning nest", enables a farmer to harvest it for fodder safely above cattle height (Olsen, Rissington). It is most important to create a safer position when cutting trees for fodder supply, as this makes pruning safer and easier. Livestock are often milling around and keen to eat the chopped branches, so when a short ladder is used, it has to be roped to the tree to prevent the farmer being stranded. 
The method used to cut trees depends on the branch diameter (Olsen and Charlton, 2003):

- Small branch (up to $30 \mathrm{~mm}$ diameter) - use a simple backcut.

- Large branch (30-100 mm diameter) - use a scarf and backcut.

- Greater than $100 \mathrm{~mm}$ diameter - use a scarf, side cuts and racing backcut, to avoid the dangerous "barbers chair" situation, which can knock the tree pruner out of the tree.

The most commonly used tree pruning methods are shown in Figure 1.

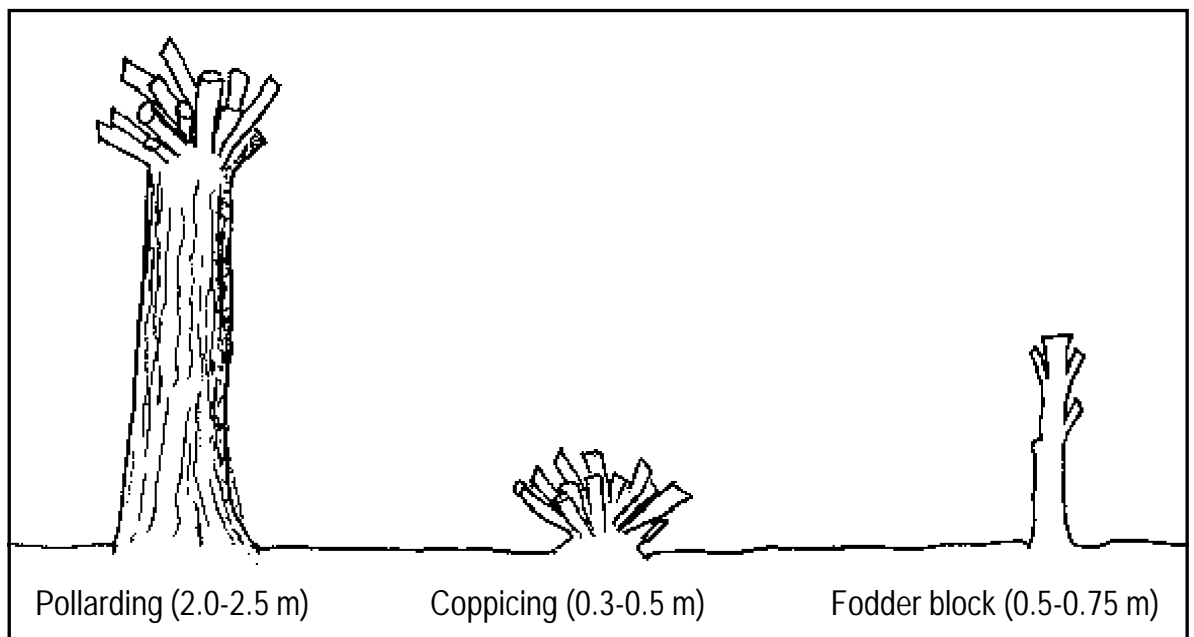

Figure 1. Commonly used tree-pruning methods for harvesting tree fodder.

\section{Coppices and browse blocks}

Several farmers use trees in coppices in the southern North Island. A coppice is an area of pasture and small trees grown for periodic cutting. By definition, coppicing necessitates cutting trees to near ground level (e.g. $0.3-0.5 \mathrm{~m}$ height), annually or biennially, with the tree foliage being eaten on-site by farm livestock, or carried elsewhere to them. Some farmers use tree blocks for periodic feeding with negligible cutting, and these are referred to as "browse blocks" (Douglas et al. 2003) as both the trees and the understorey pasture are grazed. These tree blocks usually comprise willows, though one farmer is growing a block of tagasaste (tree lucerne).

Willows provide good quantities of edible biomass in coppice blocks where the poles are planted close together, usually (but not necessarily) in rows (Kemp et al. 2001). Row planting enables a block to be grazed row-by-row, using an electric fence to ration the fodder, whereas grazing control is not so easy when poles are planted further apart or in random patterns to suit the topography (Horton, Waipawa). 
One farmer (Gordon, Taihape) planted a fodder block in spring 2001 using Kinuyanagi poles obtained from HortResearch in 1994, and these were grazed by cattle annually, but cut to $1.5 \mathrm{~m}$ height in 2,000 to grow stakes for further planting. Cuttings left on the ground in this block also sprouted, creating a denser fodder block. This farmer planted 4,000 Kinuyanagi (Japanese fodder willow) one-metre stakes, and spaced them at $3 \mathrm{~m}$ apart, to develop a new browse fodder block on 7 ha of a previously eroding northwest facing slope. After fifteen months these stakes had grown to 1.5 $\mathrm{m}$ height on the steeper slopes and in a low-lying wetter area they were $2.5 \mathrm{~m}$ tall. A year later, he planted some $1.5-2.5 \mathrm{~m}$ poles $(3-5 \mathrm{~cm}$ diameter) in one corner of the block and these overtook the 15-month-old trees grown from stakes. He reports that the taller and thicker the poles are, the better they grow. A second 2 ha block, another section of the same slip-prone slope, will be planted with Tangoio willow poles to extend the fodder block resource.

Another Rangitikei farmer (Baird, Mangaweka) is investigating cuttings left to sprout as an establishment method for blocks, and tying down young trees to encourage lateral growth.

\section{Utilising leaf fall}

Several farmers rated falling leaves very highly as feed during a drought. Drought conditions usually develop during late summer/early autumn and poplar trees respond by shedding their foliage to minimise transpiration (McGregor et al. 1999). Leaves shed are fresh and palatable, compared with most available pasture at this stage, and the livestock eat all available leaves as they land. Feed quality of intact leaves of poplar and willow in summer/autumn is usually similar to or slightly higher than that of pasture during the same period, particularly during drought (Kemp et al. 2001, 2003), and they are rich in trace elements such as zinc. However the quality of fallen leaves declines rapidly over time with for example Douglas et $a l$. (in prep.) finding that organic matter digestibility of intact poplar leaves was $76 \%$, declining to $61 \%$ for recently fallen leaves ( 2 or 3 days on the ground; 80 $90 \%$ green), to $46 \%$ for older leaves (> 20 days on the ground; > $90 \%$ brown). Similarly, soluble carbohydrate concentration declined from $16.8 \%$ for intact leaves to $4.4 \%$ for old leaves. $\mathrm{Li}$ (1984) found that Chinese shelterbelts comprising poplar trees provided large quantities of fodder for sheep, and their nutritive value was similar to herbage.

\section{Grazing value}

Most farmers reported that they found tree fodder feeding a valuable practice and well worthwhile. One farmer (Gawith, Longbush) reported taking 1.5-2 hours per day to feed 1,000 sheep using a chainsaw to cut the trees. He has been using trees as fodder for the past 15 years but feels it is only worthwhile as a supplement to boost lambing percentage. He has fed 1,000-1,500 ewes on tree fodder for up to six weeks in a given year, rotating them with some on better pasture. As most hill 
country farmers have cattle as well as sheep, feeding tree prunings can occupy up to 4 hours a day for 7 days a week.

Another Wairarapa farmer (Langdon, Tinui) reported harvesting 5-6 trees per day to feed approximately 1,000 ewes for a three- to four-week period. He was unconcerned about tree feeding being cost-effective, as he knew he had to feed his livestock during desperate pasture feed shortages. He used tree fodder for 20 years before stopping in 1991 because of safety concerns, as his trees were more than 40 years old and tree limbs had grown too big, making cutting operations dangerous. These trees had to be removed.

Another Wairarapa sheep and beef farmer (Canning, Tinui) has 70 ha planted with poplar and willow hybrids for soil conservation, and only started pruning these as drought fodder in 1998-99. Chopping tree fodder daily and seeing the stock relish it and maintain condition boosted his morale and made tree pruning worthwhile.

Poplar trees up to 20 years old, growing on 45 ha of a Wairarapa farm, provided feed for 200 mixed-age beef cows for two months (Treeby 1978). After all the younger trees had been used, 3-4 large trees were pruned or pollarded daily.

A Rangitikei farmer (Baird, Mangaweka) reported feeding 250 ewe lambs on an orchard area, and another Rangitikei farmer (Hocking, Bulls) grew tree and shrub trial blocks in the 1980s and 1990s, hosted willow fodder research trials (Douglas et al. 1996) and recently planted poplars specifically for fodder. Tagasaste was also planted in the mid 1980s but feeding this was more difficult than willows and poplars, however cows grazed it readily.

\section{Otago farm experience}

The use of trees for fodder increased in 1988 following a severe drought in North and East Otago, and the Otago Regional Council supplied surplus Flevo poplar stakes free of charge to farmers in these districts to establish tree feed banks. Establishment was generally of variable success but a good block of 1.5 ha planted at $5 \times 5 \mathrm{~m}$ (400 stems per hectare) was established on the property of John and Heather Prebble at Dunback, East Otago. Growing poplars in an East Otago climate with an average rainfall of $650 \mathrm{~mm}$ per annum, varying from $400-1,000 \mathrm{~mm}$, proved a challenge and it was found that poplars did not thrive in soils without the gravel base found in adjacent recent soils.

By 1998, when the next drought occurred, the poplars had reached a height of approximately $10 \mathrm{~m}$. They were cut to $1 \mathrm{~m}$ above ground level and fed to cattle. This method was safe and easy, as no tree climbing was required. The coppice regrowth from this method was impressive and within five years (by 2003), growth of up to $8 \mathrm{~m}$ had been achieved on 6-8 coppiced branches per stump, with a 
massive quantity of accumulated fodder in the leaves. This time the trees were fed to sheep with a small supplementary diet of grain and no other roughage.

Experience shows that it is essential to exclude stock while stumps establish new shoots. Thereafter the pasture in the block can be grazed as usual until the poplars are needed again. The only downside is the bulk of branches left after the leaves are eaten. These are offered to town friends for firewood.

Drought conditions were experienced in Coastal Otago again in summer 2002-2003. Poplar trees originally planted in 1986 for selection and conservation use on John Adam's Henley property proved extremely useful for stock forage as pasture growth slowed dramatically early in 2003. The block contains about 350 mature poplar trees of varying parentage (predominantly $P$. deltoides $\mathrm{x}$ nigra clones) at $10 \times 10 \mathrm{~m}$ spacing. Mean tree height is now about $19 \mathrm{~m}$ and diameter at breast height (DBH) ranges from 190 to $320 \mathrm{~mm}$. Up to 50 trees at a time were pruned to a height of about $8 \mathrm{~m}$, which took an experienced silviculturalist about two hours. In total some 200 trees were trimmed over four occasions. This provided feed for 1,000 sheep and some cattle that were given access to this fodder over a 3-4 week period.

Similarly, drought in summer 2002-2003 reduced pasture dry matter production by $40-60 \%$, relative to the pervious year's measurements at Wayne McNeish's property near Lawrence, Otago (Douglas et al. 2001). Stress-induced leaf loss from poplars planted in the early 1990s supplied extra feed required for the crossbred ewes grazing the blocks. Shelter was an added benefit for the stock.

\section{Management plan for soil conservation trees used as fodder}

Based on the farmers' experiences, the following management from planting to the end of tree life is recommended:

$\begin{array}{cl}\text { Year } & \text { Procedure } \\ 1 & \text { Plant pole and protect from stock by fencing or plastic } \\ & \text { sleeves } \\ 2 & \text { Maintain protection and control weeds if necessary } \\ 3 & \text { Light prune and initial feed use during late summer } \\ 4 & \text { Keep trunk protected from stock } \\ 5 & \text { Prune/pollard at } 2.0-2.5 \mathrm{~m} \text { above ground } \\ \text { Subsequent years } & \begin{array}{l}\text { Prune every 2-3 years (regardless of drought), to keep trees } \\ \text { at reasonable size. }\end{array}\end{array}$

\section{Acknowledgements}

The following farmers are thanked for their generous co-operation in supplying relevant information: Wairarapa: Peter Gawith, Longbush, Gladstone; John Canning, 
Tinui; John Langdon, Tinui. Hawke's Bay: Ewan McGregor, Hautope, Waipawa; Geoff Horton, Castlehill Station, Elsthorpe; Alec Olsen, Rissington; Marty and Rob Ennor, Nicholls Road, Waipukurau. Rangitikei: Fraser Gordon, Wairere, Taihape; Grant Baird, Kauwhatau Valley, Mangaweka; Denis Hocking, Bulls; Les Rowlands, Taihape; Don Tantrum, Rangiwaea. Otago: John Prebble, Dunback; John Adam, Henley; Wayne McNeish, Lawrence.

\section{References}

Douglas, G.B.; Bulloch, B.T.; Foote, A.G. 1996. Cutting management of willows (Salix spp.) and leguminous shrubs for forage during summer. New Zealand Journal of Agricultural Research 39: 179-184.

Douglas, G.B.; Walcroft, A.S.; Wills, B.J.; Hurst, S.E.; Foote, A.G.; Trainor, K.D.; Fung, L.E. 2001. Resident pasture growth and the micro-environment beneath young, wide-spaced poplars in New Zealand. Proceedings of the New Zealand Grassland Association 63: 131-138.

Douglas, G.B.; Barry, T.N.; Faulknor, N.A.; Kemp, P.D.; Foote, A.G.; Cameron, P.N.; Pitta, D.W. 2003. Willow coppice and browse blocks: establishment and management. In Proceedings of the Sustainable Farming Fund Tree Fodder Workshop, Palmerston North. Grasslands Research and Practice Series No 10 2003: 41-52.

Everist, S.L. 1958. Our best fodder trees. Queensland Journal of Agriculture 84: 581-582.

Hyslop, P. 1999. Meeting the market in a dry environment. Proceedings of the New Zealand Grassland Association 61: 99-100.

Kemp, P.D.; McKay, A.D.; Matheson, L.A.; Timmins, M.E. 2001. The forage value of poplars and willows. Proceedings of the New Zealand Grassland Association 63: 115-119.

Kemp, P.D.; Barry, T.N.; Douglas, G.B. 2003. Edible forage yield and nutritive value of poplar and willow. In Proceedings of the Sustainable Farming Fund Tree Fodder Workshop, Palmerston North. Grassland Research and Practice Series No 10: 53-64.

Li, D.W. 1984. Investigations on utilising the fallen leaves from forest belts of Populus nigra var. italica as winter fodder for sheep. Forest Science and Technology (Linye Keji Tongxun) 6: 20-21.

McGregor, E.; Mackay, A.D.; Dodd, M.; Kemp, P.D. 1999. Silvopastoralism using tended poplars in New Zealand hill country: the opportunities. Proceedings of the New Zealand Grassland Association 61: 85-89.

Nautiyal, S. 1991. Willow: a multipurpose tree of cold desert in India. Indian Forester 117: 153-155.

Poole, A.L. 1983. Catchment control in New Zealand. Water and Soil Miscellaneous Publication No. 48. National Water and Soil Conservation Authority, Wellington, New Zealand. 185pp. 
Olsen, A.G.; Charlton, J.F.L. 2003. Practical tree fodder experience during drought. In Proceedings of the Sustainable Farming Fund Tree Fodder Workshop, Palmerston North. Grassland Research and Practice Series No 10: 17-22.

San Miguel, A.; Gonzalez, A.F. 1985. Possibilities of using poplars as fodder in Spain. Anales del Instituto Nacional de Investigaciones Agrarias Forestal 9: $75-86$.

Schwartz, C.C.; Regelin, W.L.; Franzmann, A.W. 1988. Estimates of digestibility of birch, willow and aspen mixtures in moose. Journal of Wildlife Management 52: 33-37.

Treeby, B. 1978. Poplars: high quality stock food. Farm Forestry 20: 110-112.

van Kraayenoord, C.W.S.; Hathaway, R.L. (eds.) 1986. Plant materials handbook for soil conservation Volume 1. Principles and Practices. Water and Soil Miscellaneous Publication No. 93. National Water and Soil Conservation Authority, Wellington, New Zealand. 296pp.

Wilkinson, A.G. 1999. Poplars and willows for soil erosion control in New Zealand. Biomass and Bioenergy 16: 263-274. 
